\title{
A paleopathological case of pituitary tumor, Eagle's syndrome and ossifying fibroma
}

\author{
Corresponding author: \\ Abdulla Al-Shorman \\ Department of Anthropology, Faculty \\ of Archaeology and Anthropology \\ Yarmouk University, Jordan \\ alshorman@yu.edu.jo \\ Medical Research Journal 2018; \\ Volume 3, Number 2, 98-101 \\ 10.5603/MRJ.2018.0016 \\ Copyright (C) 2018 Via Medica \\ ISSN 2451-2591
}

\begin{abstract}
The salvage excavation in Mafraq region in Jordan uncovered a Byzantine female skull that died at an age of 18-25 years old. The visual and x-ray examination revealed diagnoses of pituitary adenoma, Eagle's syndrome, and maxillary ossifying fibroma. In addition, the case suffered a very poor oral health; dental caries, abscesses, and periodontal disease.
\end{abstract}

Key words: Pituitary tumor, Eagle's Syndrome, Ossifying fibroma, Byzantine, Jordan

Med Res J 2018; 3 (2): 98-101

\section{Introduction}

Numerous diseases in the Byzantine period of Jordan were prevalent and had a high morbidity, such as osteoarthritis [1], periodontal diseases [2-4], anemia and rickets [5-7], infectious diseases [8-9], trauma [10], Paget's disease [11-12], and the Justinianic Plague from 541-750 AD [13], which caused massive loss of life on recurrent occasions [14]. The lack of reported tumorous lesions in the Byzantine skeletal materials is undoubtedly owing to the reliance on anthroposophical investigation by bioarchaeologists rather than a systematic radiological examination, and probably to the infrequent occurrence of such lesions on bones. This study reports a number of paleopathological lesions of a case from the Mafraq region in northeastern Jordan dating to the Late Byzantine period. These lesions were rare as being not reported in the bioarchaeological literature of Jordan.

\section{Materials and methods}

The skull was found after salvage archaeology at Mafraq in northern Jordan without the post cranial skeleton, it has an excellent state of preservation except for a postmortem fracture in the right parietal bone. Based on the associated pottery sherds, a Late Byzantine date was concluded (450-640 AD). The skull was examined visually and then using $x$-ray in the lateral projection.

\section{Results}

The age at death is estimated to be 17-25 years based on tooth attrition [15] and 18-44 years based on the vault sutures [16] yielding an approximate age of about 18-25 years. The size of the mastoid process, the surface of the nauchal area, the thickness of the supra-orbital margins, the profile of the supra-orbital ridge and the mental eminence indicate a female sex [17].

The styloid process was elongated; it was measured from its base to the apex, the point where the styloid process extended from the temporal bone [18], yielding a length of $27 \mathrm{~mm}$ without the broken tip. The normal length is from $20-25 \mathrm{~mm}$ [19]. In addition, the process is extremely slanted anteriorly towards the ascending ramus of the mandible (Fig. 1). The elongation and slanting could have caused head, neck and throat pain described as Eagle's syndrome [20].

The inferior portion of the maxilla exhibits four irregular bump-like bony growths superior to the greater palatine groove and adjacent to the alveolar bone of the molars (about $5 \times 5 \mathrm{~mm}$ ), and with central cavities (Fig. 2). This growth indicates a diagnosis of ossifying fibroma, which is a benign and painless tumor [21]. The cause of this disease is unknown and originates in the desmodontal cells of the alveolodental ligament [22]. It is common between the third and fourth decade of life and more frequent in women than in men [23]. 


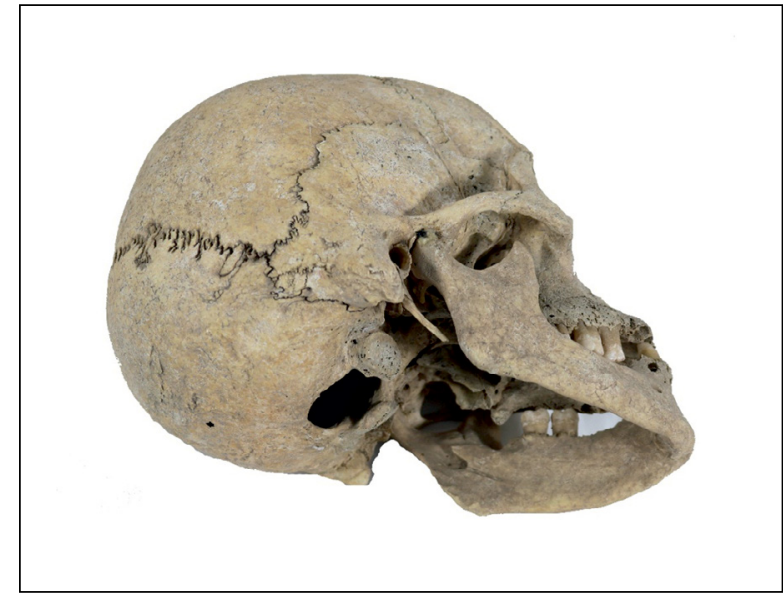

Figure 1. A lateral view of the skull showing the elongated styloid process, photographed by $\mathrm{H}$. Deebajah

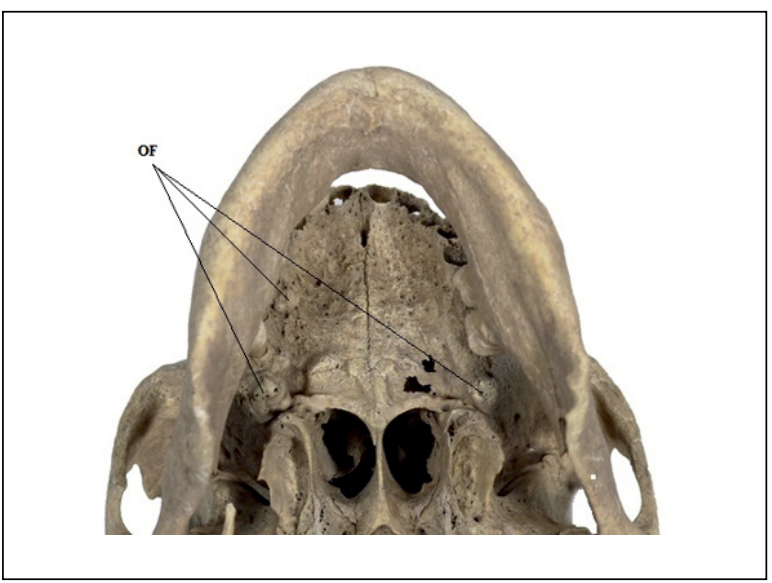

Figure 2. Ossifying fibromas (OF) of the maxilla, photographed by H. Deebajah

Premortem tooth loss, dental caries (buccal and interproximal), alveolar abscesses, and periodontal disease were also noted (Fig. 3). The oral health of the individual indicates a poor oral hygiene and a diet rich in carbohydrates [6].

The x-ray examination showed a cup-shaped enlargement of the sella turcica, marked thinning of the left posterior clinoid process with exostosis, and marked thinning of the sellar floor (Fig. 4). A normal pituitary gland measures about $8 \mathrm{~mm}$ in its length (greater anteroposterior diameter) and $12 \mathrm{~mm}$ in its traverse [24]. The average radiographic measurements of the normal adult sella have been given as length $10.6 \mathrm{~mm}$ and depth $8 \mathrm{~mm}$ [25]. The modern population of Jordan has an average length of $8.72 \mathrm{~mm}$ and width $7.68 \mathrm{~mm}$ [26]. The incidence rate of pituitary adenoma among Jordanians is $9.3 \%$ [27]. The length and depth measurements were exceeded in this case as the length is $17 \mathrm{~mm}$ and the depth is $9 \mathrm{~mm}$. In addition, the skull bones are thick

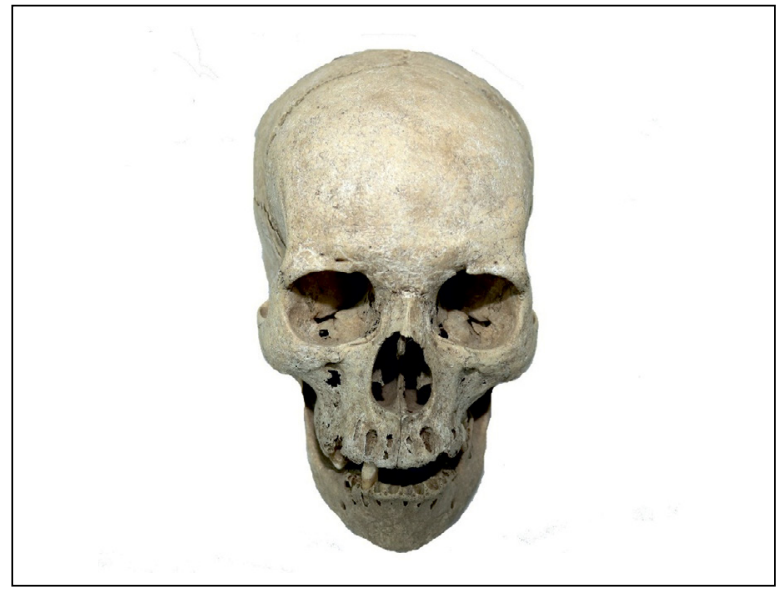

Figure 3. Anterior view of the skull showing dental abscesses and periodontal disease, photographed by $\mathrm{H}$. Deebajah

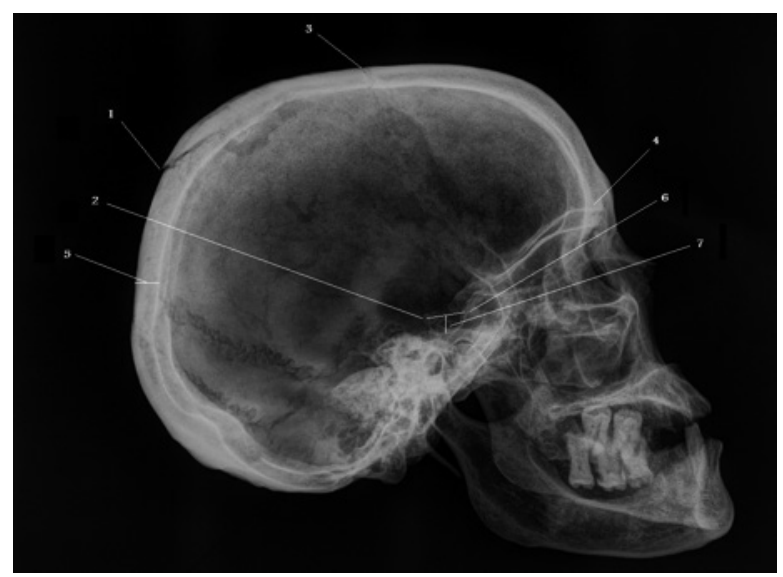

Figure 4. Skull lateral $\mathrm{x}$-ray, 1 and 3 are postmortem fractures, 4 - closed frontal sinuses, 6 - length of the sella turcica, 7 - depth of the sella turcica, 2 - dorsum exostosis, and 5 - bone thickness

(about $1 \mathrm{~mm}$ ) compared to normal. The morphological changes in the sella turcica suggest a pituitary tumor with evidence of a marked intracranial pressure as shown by thick skull bones [28-29]. Frontal sinuses aplasia is also noted in the radiograph, which could be a normal variant among humans and occurs in 5\% of normal adults [30], or a sign of acromegaly in pituitary adenoma [31].

\section{Discussion}

Approximately $4 \%$ of the living population have an elongated styloid process but not necessarily develop symptoms of Eagle's syndrome [32]. The symptoms may include dysphagia, neck pain, and a sensation of foreign object in the back of throat [33]. Few cases 
of Eagle's syndrome were reported in the paleopathological literature [34-37], where none of them was reported from Jordan. The first case of ossifying fibroma in paleopathological literature was reported by Colrad et al. [38] from Pas-de-Calais region in France, dated to the $6^{\text {th }}-7^{\text {th }}$ century $A D$. Their investigation revealed a large lesion $(30 \times 20 \mathrm{~mm})$ that occupied the right maxilla; they claimed that the lesion could have caused ophthalmological signs, such as, lachrymation, ptosis and exophthalmia. The fibroma of current case is relatively small suggesting a death before the progression of disease.

The tumor of the presented case would have caused a considerable increase in the volume of the pituitary and probably attributed to the bone exostosis in the posterior clinoid process. The generated pressure of the pituitary usually impairs the optic chiasm and, thus, visual impairment [39]. The thickness of the cranial bones associated with frontal sinus aplasia refers to a tumor that was acromegalic. Accordingly, the most probable diagnosis is a secreting pituitary adenoma. However, there have been few archaeological cases that illustrate the pituitary tumor in skeletal material [29, 31, 40-41], which signifies the rarity of the disease in antiquity.

Skeletal remains are the second most abundant material in Jordan's archaeological sites, where careful examination aided by physical and chemical analytical techniques (e.g.: radiographic imaging) may uncover a wide array of paleopathological lesions that were thought to be absent, tumors are an example but one. Many diseases in the Byzantine period were widespread and had a high morbidity [42]. Contrary to the typical believe that the rural life of the Byzantine people in Jordan was of poor quality, the people had better health and more wealth [43-44]. However, this does not negate the presence of rare and serious diseases such as pituitary tumor.

\section{Conclusions}

Tumors were not uncommon in antiquity and probably contributed to the morbidity and mortality as they do today. The prevalence of tumors in ancient skeletal material was underestimated; however, many of them are not associated with skeletal alteration but the use of modern diagnostic techniques may prove very rewarding.

\section{References}

1. Al-Shorman A. The Evidence of Weaving at Khirbit Yajuz in Jordan Using Dental Microwear. International Journal of Dental Anthropology. 2006; 8: p. : 1-9.

2. Albashaireh Z, Al-Shorman AA. The frequency and distribution of dental caries and tooth wear in a Byzantine population of Sa'ad, Jordan. International Journal of Osteoarchaeology. 2008, doi: 10.1002/oa.1023.
3. Cheyney M, Brashler J, Boersma B, et al. Umm el-Jimal Cemeteries Z, AA, BB and CC 1996 and 1998 Field Reports. Annualof the Department of Antiqities of Jordan. 2009; 53: p. : 321-359.

4. Stirling J. The Human skeletal Remains from Hesban Cemetery. Andrews University Seminary Studies. 1978; 16(1): p. : 1-6.

5. Al-Shorman A. Geology and Anthropology: A Case Study from Jordan. Anthropologies. 2007; 45(2-3): p. : 283-289.

6. Al-Shorman AA. Byzantine Tomb from Khirbit Yajuz, Jordan. Journal of Paleopathology. 2003; 15(3): p. : 177-185.

7. Nabulsi A. The Byzantine Cemetery at Khirbit As-Samra. Annual of the Department of Antiquities of Jordan. 1996: 40: p. : 315-317.

8. Doyle A, Judd M. The forgotten pathology: Middle ear disease at Mount Nebo, Jordan. Saint Louis. ; 2015.

9. Perry M, Newnam J, Gilliland M. Differential diagnosis of a calcified object from a 4th-5th century AD burial in Aqaba, Jordan. International Journal of Osteoarchaeology. 2008; 18(5): 507-522, doi: 10.1002/oa.960.

10. Frohlich B. The Human Skeletal Series. In Ibrahim M, Gordon R A Cemetery of Queen Alia International Airort. Wiesbaden, Germany: Otto Harrassawitz; 1978. p. : 50-53.

11. Doyle A, Judd M. The forgotten pathology: Middle ear disease at Mount Nebo, Jordan. In The 84th Annual Meeting of the American Association of Physical Anthropologists; 2015; St. : Louis.

12. Kesterke M, Judd MA. Potential Case of Paget's Disease of Bone at the Byzantine Site of Robebus Chael, Mount Nebo, Jordan. In 2014 Pitt Graduate Exo; 2014: University of Pittsburgh. p. ; 1

13. Kennedy H. Justinianic Plague in Syria and. In Little L. Plaque and the End of Antiquity: The Pandemic of 541-750. Cambridge: Cambridge University Press; 2007. p. ; 95

14. Stathakooulos D. Poulation, Demograhy, and Disease. In Cormack R, Haldon J, Jeffreys E. The Oxford Handbook of Byzantine Studies. Oxford: Oxford University Press; 2008. p. : 309-317.

15. Brothwell D. Digging up Bones. 3rd ed. Oxford: Oxford University Press. ; 1981.

16. Meindl RS, Lovejoy CO. Ectocranial suture closure: a revised method for the determination of skeletal age at death based on the lateral-anterior sutures. Am J Phys Anthropol. 1985; 68(1): 57-66, doi: 10.1002/ajpa.1330680106, indexed in Pubmed: 4061602.

17. Buikstra J, Ubelaker D. Standards: For Data Collection from Human Skeletal Remains Fayettivlle, Arkansas: Arkansas Archaeological Survey. ; 1994

18. Šikanjić $P$, Vlak D. Elongated styloid process in late medieval skeletons from Uzdolje-Grablje, Croatia. International Journal of Osteoarchaeology. 2008, doi: 10.1002/oa.1022.

19. Balcioglu HA, Kilic C, Akyol M, et al. Length of the styloid process and anatomical implications for Eagle's syndrome. Folia Morphol (Warsz). 2009; 68(4): 265-270, indexed in Pubmed: 19950078.

20. Fotis D, Mannucci A, Vercellotti G. A possible case of Eagle's syndrome from an Italian ossuary (Chiavari, GE). Cranio. 2013; 31(1): 61-65, doi: 10.1179/crn.2013.009, indexed in Pubmed: 23461264.

21. Civelek B, Oktem F, Karamursel S, et al. A rare entity: cemento-ossifying fibroma. Plast Reconstr Surg. 2005; 116(7): 2049-2050, indexed in Pubmed: 16327639

22. MacDonald-Jankowski DS. Fibro-osseous lesions of the face and jaws. Clin Radiol. 2004; 59(1): 11-25, indexed in Pubmed: 14697371.

23. Eversole LR, Leider AS, Nelson K. Ossifying fibroma: a clinicopathologic study of sixty-four cases. Oral Surg Oral Med Oral Pathol. 1985; 60(5): 505-511, indexed in Pubmed: 3864113

24. Standring S. Grey's Anatomy: The Anatomical Basis of Clinical Practice. 41st ed. Philadelphia: Elsevier. ; 2016.

25. Keats T, Lusted L. Atlas of Roentgenographic Measurement. 5th ed. Chicago: Year Book Medical Publishers. ; 1985.

26. Abu Ghaida JH, Mistareehi AJ, Mustafa AG, et al. The normal dimensions of the sella turcica in Jordanians: a study on lateral cephalograms. Folia Morphol (Warsz). 2017; 76(1): 1-9, doi: 10.5603/FM.a2016.0038, indexed in Pubmed: 27830892

27. Tamimi AF Tamimi I, Abdelaziz M et al. Epidemiology of Malignant and Non-Malignant Primary Brain Tumors in Jordan. Neuroepidemiology. 2015; 45(2): 100-108, doi: 10.1159/000438926, indexed in Pubmed: 26314301

28. Camp J. Normal and pathological anatomy of sella turcica as revealed by roentgenograms. American Journal of Roentgenology. 1924; 12 : p. : $143-156$

29. Canci A, Repetto E, Tarli S. Sellar Pathology in a middle Bronze Age skull from Southern Italy. International Journal of Osteoarchaeology. 1992; 2(4): 305-310, doi: 10.1002/oa.1390020406.

30. Scuderi AJ, Harnsberger HR, Boyer RS. Pneumatization of the paranasal sinuses: normal features of importance to the accurate interpretation of CT scans and MR images. AJR Am J Roentgenol. 1993: 160(5): 1101-1104, doi: 10.2214/ajr.160.5.8470585, indexed in Pubmed: 8470585. 
31. Hacking P. A pituitary tumour in a medieval skull. International Journal of Osteoarchaeology. 1995; 5(4): 390-393, doi: 10.1002/oa.1390050410.

32. Petrović B, Radak D, Kostić V, et al. [Styloid syndrome: a review of literature]. Srp Arh Celok Lek. 2008; 136(11-12): 667-674, indexed in Pubmed: 19177834.

33. Silva HJ, Moraes S, Santos L, et al. DISSECTION OF THE STYLOHYOID CHAIN: A METHOD OF APPROACH. Revista chilena de anatomía. 2001; 19(2), doi: 10.4067/s0716-98682001000200004.

34. Ozdemir MB, Okunak M, Koseler A, et al. An ancient anatomic variation: bilateral elongated styloid process of cranium. Ital J Anat Embryol. 2013; 118(2): 184-188, indexed in Pubmed: 25338408.

35. Usayl G. An Early Byzantine Case of Eagle's Syndrome in Turkey. Paleopathology Newsletter. 2006; 133: p. : 14-16.

36. Gerszten PC, Gerszten E, Allison MJ. Diseases of the skull in pre-Columbian South American mummies. Neurosurgery. 1998; 42(5): 1145-51; discussion 1151, indexed in Pubmed: 9588561.

37. Sawyer DR, Allison MJ, Pezzia A. Elongated styloid process in a pre-Columbian Peruvian. J Dent Res. 1980; 59(1): 79, doi 10.1177/00220345800590011401, indexed in Pubmed: 6985919
38. Colard T, Gabart N, Blondiaux J. A palaeopathological case of a right maxilla's cemento-ossifying fibroma. International Journal of Osteoarchaeology. 2008; 18(2): 195-201, doi: 10.1002/oa.936.

39. Kovacs K, Horvath E. Tumors of the Pituitary Gland, Atlas of Tumor Pathology (11 series) Washington: Armed Forces Institute of Pathology. ; 1983.

40. Hawkins $D$. The diagnosis of pituitary disease from human skeleta remains. International Journal of Osteoarchaeology. 1992; 2(1): 51-64 doi: 10.1002/oa.1390020108.

41. Ortner D, Putschar W. Identification of pathological conditions in human skeletal remains. Smithsonian Contributions to Anthropology. 1985(28): 1-488, doi: 10.5479/si.00810223.28.1.

42. Eftychiadis AC. Diseases in the Byzantine world with special emphasis on the nephropathies. Am J Nephrol. 1997; 17(3-4): 217-221, doi: 10.1159/000169226, indexed in Pubmed: 9189237.

43. Rose J, Burke D. Sa'ad: A Late Roman/Byzantine Site in North Jordan Irbid: Yarnouk University Press. ; 2004.

44. El-Najiar M, Barnes J. Skeletal Biology and Pathology of the Peole of Ya'amun. In . Ya'mun: An Archaeological Site in Northern Jordan. Amman: Jodan Press Foundation; 2011. p. : 217-228. 